\title{
Between Dante and Caesar. The Vernacular Policy of Filippo Maria Visconti
}

\author{
PAOLO PONZÙ DONATO
}

\begin{abstract}
This paper offers a new perspective on vernacular literature in Milan in the 1430s, when Duke Filippo Maria Visconti commissioned from the humanists of his court vernacular translations of ancient histories and commentaries on Dante's Comedy and Petrarch's Canzoniere. These works, often dismissed as courtly products, were part of an ambitious cultural project that was carried out by humanists like Filippo Maria's secretary Pier Candido Decembrio and Guiniforte Barzizza, but their attitude toward the duke's commissions betrays their uneasiness with vernacular literature. It was the duke of Milan who, having sensed the political impact of promoting vernacular literature in Milan, intended to take over from Florence the role of driving force of Italian literature. Had not the Visconti army been defeated at Anghiari in 1440, Filippo Maria would have further pursued his ambition to politically and linguistically unify Italy under Milan's rule.
\end{abstract}

In his Vita Philippi Mariae Vicecomitis (Life of Filippo Maria Visconti, 1447), Pier Candido Decembrio offers a vivid account of Duke Filippo Maria Visconti's education and reading:

As a child [Filippo Maria Visconti] was educated by his private tutor Giovanni da Thiene [...] Filippo's core curriculum in literature consisted in the sonnets of Petrarch, written in Italian verse. The young man was so affected by his reading of these poems that when he became duke he insisted that someone in his entourage be designated to comment on and elucidate them. And it was he himself who established the order in which he wanted the sonnets to be read. He also listened with the greatest attention to Marziano da Tortona, whose lectures focused on the vernacular works of Dante. He listened to readings from Livy as well, but in no particular order, preferring rather to select the highlights, 
and to home in on the passages he found to be most instructive. When the diplomatic correspondence was being read, he could understand it without the aid of a translation, even though his grasp of Latin was not the best. [...] He also enjoyed reading the French chansons de gestes that spin such tall tales regarding the heroes of old. He listened with great delight as well to histories relating the deeds of famous men, whether in their established vernacular versions, or as translated by humanists from Latin. ${ }^{1}$

In this passage, the striking reoccurrence of the verb "to listen" (or "to be read to") implies that Visconti was chiefly seen as an individual who listened to a broad range of historiographical and literary texts. Indeed, as with ancient historiography and the chivalric novels, the ancient historians in translation could also be read aloud, for the pleasure of the court or noble households. ${ }^{2}$ Moreover, Decembrio establishes a direct link between the literary tastes of the duke of Milan and the literary studies he promoted at his court. ${ }^{3}$ In other words, according to Decembrio, the fact that Filippo Maria Visconti, after becoming duke, encouraged the humanists in his service to comment on the works of Petrarch and Dante is explained by his fascination with those works. The duke's passion for Livy's histories and for ancient history in general, together with his imperfect grasp of the Latin language, led him to commission vernacular translations of ancient histories. Thus, Decembrio suggests that literary studies at Filippo Maria Visconti's court were subject to the logic of the plenitude of power (plenitudo potestatis), according to Baldo degli

1 G. Ianziti (tr.), M. Zaggia (ed.), Pier Candido Decembrio, Lives of the Milanese Tyrants (Cambridge, MA - London, 2019), 125.

2 On this see R. Walker, "Oral Delivery or Private Reading? A Contribution to the Debate on the Dissemination of Medieval literature", Forum for Modern Language Studies 7 (1971), 36-42, and N. Zemon Davies, Society and Culture in Early-Modern France (London, 1975), 200-203.

3 On humanism in early fifteenth century Milan, see E. Garin, "La cultura milanese nella prima metà del sec. XV”, in Storia di Milano, vol. 6 (Milano, 1955), 547-608; A. Rabil, "Humanism in Milan", in Id., Renaissance Humanism. Foundations, Forms, and Legacy, vol. 1 (Philadelphia, PA, 1988), 235-263; M. Zaggia, "Appunti sulla cultura letteraria in volgare a Milano nell'età di Filippo Maria Visconti”, Giornale storico della letteratura italiana 170 (1993), 161-219, 321-382; Id., "Linee per una storia della cultura in Lombardia", in L.C. Rossi (ed.), Le strade di Ercole: itinerari umanistici e altri percorsi. Seminario internazionale per $i$ centenari di Coluccio Salutati e Lorenzo Valla (Bergamo, 25-26 ottobre 2007) (Firenze, 2010), 3-125. For an overview on the economic, political, and cultural environment of Milan, see A. Gamberini (ed.), A Companion to Late Medieval and Early Modern Milan: The Distinctive Features of an Italian State (Leiden - Boston, MA, 2014). 
Ubaldi's definition: "whatever the prince likes [or decrees] has the force of law" ("quidquid regi placet legis habet vigorem"). ${ }^{4}$ In actual fact, the literary studies encouraged by Filippo Maria Visconti did not simply conform to the duke's personal tastes, as Decembrio writes, but rather were part of a specific cultural project whose aim was to make Milan the new capital of the Italian language and Italian literature, at the expense of Florence. $^{5}$

Following the example of his father, Duke Gian Galeazzo Visconti, who used to say that one of Coluccio Salutati's epistles harmed him more than a thousand horsemen in the service of his rival Florence, ${ }^{6}$ Filippo Maria Visconti was well aware that the literary arena could be more decisive than the battlefield in his struggle to impose his leadership. However, if Gian Galeazzo ordered his secretary Antonio Loschi to wage an epistolary war against Salutati, Filippo Maria turned out to be much more ambitious, especially in the decade that brought Milan and Florence to the battle of Anghiari (29 June 1440) - the decade that saw in Milan not simply a courtly humanism, but another vision of humanism entirely, one that eventually succumbed to the Florentine humanistic ideal. ${ }^{7}$

To better understand this crucial point, we need to consider another key work by Pier Candido Decembrio, his De laudibus Mediolanensium urbis panegyricus (Panegyric in Praise of the City of the Milanese), written in 1436 in response to Leonardo Bruni's Laudatio Florentine urbis

4 See J. Black, Absolutism in Renaissance Milan: Plenitude of Power under the Visconti and the Sforza, 1329-1535 (Oxford, 2009), 18-29.

5 This interpretation was suggested by Zaggia 1993 (as in n. 3), 189-208. See also A. Rizzi, Vernacular Translators in Quattrocento Italy: Scribal Culture, Authority, and Agency (Turnhout, 2017), 83-89. On Decembrio's historiographical strategies, see G. Ianziti, "Pier Candido Decembrio and the Beginnings of Humanist Historiography in Visconti Milan", in N.S. Baker, B.J. Maxson (ed.), After Civic Humanism: Learning and Politics in Renaissance Italy (Toronto 2015), 153-172); Id., "Pier Candido Decembrio and the Suetonian Path to Princely Biography", in P. Baker, R. Kaiser et al. (ed.), Portraying the Prince in the Renaissance: the Humanist Depiction of Rulers in Historiographical and Biographical Texts (Berlin, 2016), 237-270. See also J. Hankins, Virtue Politics: Soulcraft and Statecraft in Renaissance Italy (Cambridge, MA - London, 2019), 141-147.

6 See F. Novati (ed.), Coluccio Salutati, Epistolario, vol. 4 (Roma, 1911), 514 and n. 2 .

7 On the Battle of Anghiari seen by the Milanese part, see F. Cognasso, "Il ducato visconteo da Gian Galeazzo a Filippo Maria”, in Storia di Milano, vol. 6 (Milano, 1955), 1383 , at 332-339. 
(Praise of the City of Florence, 1404), which could be regarded as the political manifesto of Visconti Milan. ${ }^{8}$

\section{The Myth of Imperial Rome and Caesarism at a Princely Court}

In his panegyric of Milan, Decembrio famously challenges Bruni's republicanism by extolling Milan's imperial tradition, stating:

Not unjustly did the ancients give this city the name of 'Second Rome', a civic glory that both Florence and the other illustrious Italian cities have always lacked. It seems to me that such preeminence was attributed to the Milanese people because they would restore to its original splendor the empire's strength, declining in favor in another part of the world [= the Eastern Roman Empire], and they would not allow the name of Italy to be robbed of the ancient dignity of their ancestors. ${ }^{9}$

It is interesting to note that Decembrio here does not quote the Latin poet Ausonius, who visited Milan in 379 and dedicated a famous poem to that

8 On Bruni's Laudatio, see H. Baron, Humanistic and Political Literature in Florence and Venice at the Beginning of Quattrocento. Studies in Criticism and Chronology (Cambridge, MA, 1955), 69-113; Id., From Petrarch to Leonardo Bruni. Studies in Humanistic and Political Literature (Chicago, 1968), 232-263; C. Vasoli, "Considerazioni sulla Laudatio urbis Florentinae di Leonardo Bruni", in Id., Studi sulla cultura del Rinascimento (Manduria, 1968), 48-68; A. Santosuosso, "Leonardo Bruni Revisited: a Reassessment of Hans Baron's Thesis on the Influence of the Classics in the Laudatio Florentinae Urbis", in J.G. Rowe (ed.), Aspects of Late Medieval Government and Society: Essays Presented to J.R. Lauder (Toronto, 1986), 25-51; S.U. Baldassarri (ed.), Leonardo Bruni, Laudatio Florentine Urbis (Firenze, 2000). The text of Decembrio's panegyric was edited by Giuseppe Petraglione in "Il De laudibus Mediolanensium urbis panegyricus di P.C. Decembrio", Archivio storico lombardo 34 (1907), 5-45, and later republished in F. Fossati, A. Butti, G. Petraglione (ed.), Petri Candidi Decembri Opuscula histórica (Bologna, 1958), 1011-1025. A modern critical edition of Decembrio's panegyric is still wanting.

9 See Fossati, Butti, Petraglione 1925-1958 (as in n. 8), 1023: "Non iniuria utique ab antiquis huic urbi secundae Romae nomen est inditum, qua gloria et Florentia caret civica et ceterae illustres Italiae urbes semper caruere. Mihi vero solet videri hac etiam de causa tantam prestantiam Mediolanensi populo attributam, ut is esset qui languentis imperii vires in alium labentes orbem propria virtute restitueret, nec antiqua et paterna dignitate italicum nomen defraudari pateretur." The translation is mine. 
city as the new capital of the Western Roman Empire (from 286), ${ }^{10}$ choosing rather to take the reference to Milan as the Second Rome from the obscure and relatively unknown dialogue De re publica libri IV (Four Books on the Commonwealth) of his father Uberto, who in turn took the reference from medieval chroniclers rather than from classical sources. ${ }^{11}$

However, Pier Candido Decembrio's praise of 'imperial' Milan was well in line with Caesarism, the predominant political ideology in Visconti Milan and at other princely courts, meaning, according to Gary Ianziti's definition, "a belief in the superiority of a political system based on strong leadership provided by an exceptional individual, whose abilities place him above the law." "12 Leonardo Bruni's civic humanism, which could be defined as a form of classical republicanism in which the citizen's personal interests are identified with those of the public body, was naturally opposed to Caesarism and to the quite similar idea of the plenitude of power. ${ }^{13}$ Thus in his Historiae Florentini populi (History of the Florentine People, 1416) Bruni makes clear that Florence is a direct descendant of the Roman Republic, having been founded by veterans of Sulla's army from Fiesole before Caesar took power, and has nothing to do with the Roman Empire. ${ }^{14}$ This was also the point of Coluccio Salu-

10 Aus. Urb. 7: "Et Mediolani mira omnia, copia rerum, / innumerae cultaeque domus, facunda virorum / ingenia et mores laeti; tum duplice muro / amplificata loci species populique voluptas / circus et inclusi moles cuneata theatri; / templa Palatinaeque arces opulensque moneta / et regio Herculei celebris sub honore lavacri; / cunctaque marmoreis ornata peristyla signis / moeniaque in valli formam circumdata limbo: / omnia quae magnis operum velut aemula formis / excellunt: nec iuncta premit vicinia Romae." See also L. Minozzi, "Contributo allo studio dell'architettura paleocristiana milanese", Aevum 12 (1938), 164-188, at 167.

11 See P. Ponzù Donato (ed.), Uberto Decembrio, Four Books on the Commonwealth De re publica libri IV (Leiden - Boston, MA, 2019), 37, 126-127.

12 Ianziti, Zaggia 2019 (as in n. 1), xxi.

13 On this definition of 'civic humanism', see Ponzù Donato 2019 (as in n. 11), 32.

14 For an overview on Bruni's historiography, see D.J. Wilcox, The Development of Florentine Humanist Historiography in the Fifteenth Century (Cambridge, MA, 1969), 1129; R. Fubini, "La rivendicazione di Firenze della sovranità statale e il contributo delle Historiae di Leonardo Bruni" and A.M. Cabrini, "Le Historiae del Bruni. Risultati e ipotesi di una ricerca sulle fonti”, in P. Viti (ed.), Leonardo Bruni cancelliere della Repubblica di Firenze. Atti del Convegno di studi (Firenze, 27-29 ottobre 1987) (Firenze, 1990), 29-62 and 247-319. See also R. Fubini, "Osservazioni sugli Historiarum Florentini populi libri XII di Leonardo Bruni", in Studi di storia medievale e moderna per Ernesto Sestan, vol. 1 (Firenze, 1980), 403-448; Id., Storiografia dell'umanesimo in Italia da Leonardo Bruni ad Annio da Viterbo (Roma, 2003), 93-164; G. Ianziti, Writing History in Renaissance Italy. Leonardo Bruni and the Uses of the Past (Cambridge, MA, 2012); Id., "Remarques historiographiques sur Leonardo Bruni historien", in L. Tanzini (ed.), Il laboratorio del 
tati's polemic against Antonio Loschi's Invectiva in Florentinos (Invective against the Florentines, 1403), where Loschi had coined the famous formula "They [that is, the Florentines] tyrannize that flourishing city [that is, Florence] under the appearance of freedom" ("florentem illam civitatem sub libertatis specie tirannizant"). ${ }^{15}$

Loschi's position was developed by Decembrio in his panegyric of Milan:

You therefore, o most learned Leonardo, wrote that the founders of Florence were the Romans; I want to trace the origins of the Milanese from the kings of the Gauls. So which people has a more noble origin? [...] Pay attention, o Milanese, and appreciate your lineage, when you realize to what extent your origin makes you supremely illustrious and distinguished among all peoples, since you do not excel in nobility only compared to foreigners, but you exceed in glory and prestige the Florentines, who descend from the Roman people. Was not the colony of Fiesole founded by Lucius Sulla while besieging the [Roman] state with force and arms? So where did the Florentines' bitter hatred of tyrants come from, [those Florentines] who descend from Sulla, the most wicked of tyrants? ${ }^{16}$

Apparently, this argument was suggested to Decembrio by Lorenzo Valla, who provided him with his best weapons for denying the republican

Rinascimento. Studi di storia e cultura per Riccardo Fubini (Firenze, 2015), 277-291; Id., "Leonardo Bruni and the Rise of Official Historiography in Renaissance Florence", in P. Howard, C. Hewlett (ed.), Studies on Florence and the Italian Renaissance in Honour of F.W. Kent (Turnhout, 2016), 431-448.

15 Salutati's invective was published in E. Garin (ed.), Prosatori latini del Quattrocento (Milano, 1952), 8-37 (on the foundation of Florence, see 17-21). Salutati's position is discussed in R.G. Witt, Hercules at the Crossroads. The Life, Works and Thought of Coluccio Salutati (Durham, NC, 1983), 247-52. On Loschi's invective, see Garin 1955 (as in n. 3), 550-556; for an overview on the polemic with Salutati, see N. Valeri, La libertà $e$ la pace. Orientamenti politici del Rinascimento italiano (Torino, 1942), 63-90.

16 See Fossati, Butti, Petraglione 1925-1958 (as in n. 8), 1021: "Romanos tu quidem, Leonarde doctissime, urbis Florentiae autores edidisti; ipse ad Gallorum reges Mediolanensium primordia referre studeo. Qui populus ex his igitur sublimius ortum ducit? [...] Attendite, viri Mediolanenses, et stirpem vestram recognoscite, cum videbitis quantum origine clari et conspicui omnium gentium maxime sitis, qui non exteris tantum nobilitate praestetis, verum Florentinis, a Romano populo ortum ducentibus, gloria et dignitate anteatis. Numquid Lucio Sylla rem publicam vi et armis obsidente, Fesulana colonia deducta est? Unde igitur Florentinis precipuum in tyrannos odium emicuit, qui a perditissimo [the edition incorrectly reads preditissimo] tyrannorum Sylla ortum deduxere?" The translation is mine. 
origin of Florence claimed by Leonardo Bruni, whom Valla disparagingly calls "Leonardo the beef" ("Leonardum bovem"). ${ }^{17}$

In the 1430s, both princely and republican ideologies found their touchstone in the figure of Caesar, as is clear in the heated controversy that broke out in 1435 between Poggio Bracciolini and Guarino Veronese on Caesar's superiority over Scipio Africanus, a topic that was already addressed by Petrarch, whose attitude evolved from a preference for Scipio in his younger years to a reappraisal of Caesar in his old age. ${ }^{18}$

It was Poggio who started the controversy, writing in April 1435 a long letter to Scipione Mainenti, bishop of Modena, which later circulated under the title De praestantia Scipionis et Caesarisrowess and in which he asserts that Scipio was the best among all ancient leaders, including Alexander the Great, and dismisses Caesar as inferior in both his military and his moral qualities. ${ }^{19}$ Using a passage of Lactantius's Divinae institutiones already quoted by Leonardo Bruni in his Laudatio Florentine urbis, ${ }^{20}$ Poggio concludes that "all learned men must condemn the name of Caesar. He was no worse parricide of his homeland than of the Latin

17 See O. Besomi, M. Regoliosi (ed.), Laurentii Valle Epistole (Patavii, 1984), 153$157,161-163$.

18 On the controversy between Poggio and Guarino, see G. Crevatin, "La politica e la retorica. Poggio e la controversia su Cesare e Scipione. Con una nuova edizione della lettera a Scipione Mainenti", in Poggio Bracciolini 1380-1980. Nel VI centenario della nascita (Firenze, 1982), 281-342; D. Canfora, La controversia di Poggio Bracciolini e Guarino Veronese su Cesare e Scipione (Firenze, 2001). For the polarizing role of Caesar in humanistic thought, see V. Brown, "Portraits of Julius Caesar in Latin Manuscripts of the Commentaries", Viator 12 (1981), 319-353; W. Speyer, "Italienische Humanisten als Kritiker der Echtheit antiker und christlicher Literatur", Abhandlungen der Akademie der Wissenschaften und der Literatur. Geistes- und sozialwissenschaftliche Klasse 3 (1993), esp. 46-57; H. Schadee, “'I Don't Know Who You Call Tyrants'. Debating Evil Lords in Quattrocento Humanism”, in Ead., N. Panou (ed.), Evil Lords. Theory and Representations from Antiquity to the Renaissance (Oxford, 2018), 172-190, at 181-188; Hankins 2019 (as in n. 5), 124-134. On Petrarch's attitude toward Caesar, see G. Martellotti, "Il De gestis Cesaris del Petrarca nel Corpus Caesarianum", Italia medioevale e umanistica 17 (1974), 281-311; G. Crevatin, "His credendum, qui rebus interfuere'. Petrarca e il De bello Gallico", Studi petrarcheschi, n.s., 6 (1989), 23-42.

19 See Canfora 2001 (as in n. 18), 118: "Nam alterius vitam multis officiis et in rem publicam meritis praeclaram constat fuisse, alterius pluribus flagitiis obductam. Scipionis liberalitas, beneficentia, pudicitia, castitas, Caesaris furta, rapinae, stupra et lasciviae ostenduntur [...] Alteri otium, pax, salus patriae, alteri discordiae, bella et patriae pernicies cordi erant [...] Alter libertatem sui populi conservavit, alter redegit in miserrimam servitutem."

20 Lact. Div. 1.15.29: “Apud Romanos deus Iulius, quia hoc scelerato homini placuit Antonio; deus Quirinus, quia hoc pastoribus visum est: cum alter gemini fratris extiterit, alter patriae parricida." 
language and the fine arts. In fact, Latin eloquence and literary studies declined together with freedom." 21 Guarino replied the following June with a long letter directly addressed to Poggio, in which he challenged point by point Poggio's negative depiction of Caesar, arguing that Caesar was neither a tyrant nor a suppressor of freedom but rather restored freedom to the Roman state by fighting against political and moral corruption. ${ }^{22}$ Guarino's argument reveals some similarities to Coluccio Salutati's depiction of Caesar in his De tyranno (On Tyranny, 1400), according to which being an enlightened but absolute ruler does not imply being a tyrant, a position that was challenged by Leonardo Bruni in his Dialogi ad Petrum Paulum Histrum (Dialogues for Pier Paolo Vergerio, 1401-1408). ${ }^{23}$ In November 1435, Poggio defended his argument against Caesar in a letter addressed to the Venetian humanist Francesco Barbaro, who eventually worked to achieve a reconciliation between Poggio and Guarino, which occurred in May 1436.24

If some scholars read the controversy between Poggio and Guarino as a certamen partium, or a rhetorical exercise, others stress its political implications, such that Poggio's praise of Scipio as the defender of the Roman Republic would suggest a parallel with Cosimo de' Medici as the defender of the Florentine Republic, while Guarino's praise of Caesar would allude to Leonello d'Este - to whom Guarino appeals as judge of

21 See Canfora 2001 (as in n. 18), ibid.: "Adde quod nomen Caesaris docti omnes viri execrari et odio habere deberent. Non enim magis patriae quam Latinae linguae et bonarum artium extitit parricida. Una enim cum libertate corruit Latina eloquentia et studia litterarum." The translation is mine.

22 On Guarino's defense of Caesar, see Canfora 2001 (as in n. 18), 14-15.

23 Salutati, who is one of the dialogue's interlocutors, says: "Verum ego, ut de me profitear, nunquam adduci potui, ut parricidam patriae suae Caesarem fuisse arbitrarer, de qua quidem re satis a me diligenter, ut mihi videor, in eo libro quem de tyranno scripsi disputatum est, bonisque rationibus conclusum, non impie Caesarem regnasse. Itaque nec parricidam fuisse unquam putabo, nec unquam desinam Caesarem in caelum tollere pro magnitudine rerum quas gessit," see P. Viti (ed.), Leonardo Bruni, Opere (Torino, 1996), 120, 122. On Salutati's De tyranno, see Baron 1968 (as in n. 8), 232-263; R.G. Witt, "The De tyranno and Coluccio Salutati's View of Politics and Roman History", Nuova Rivista Storica 53 (1969), 434-474; Id. 1983 (as in n. 15), 368-378, 380-385. On Bruni's position, see H. Schadee, "A Tale of Two Languages. Latin, the Vernacular, and Leonardo Bruni's Civic Humanism”, Humanistica Lovaniensia 67.1 (2018), 11-46, at 31-32.

24 See Canfora 2001 (as in n. 18), 15. 
the controversy - and, in a broader sense, to princely rule. ${ }^{25}$ In any case, even if anti-Caesarean rhetoric was not synonymous with civic humanism against a courtly Caesarism, it is evident that the positions held by Guarino and Decembrio should not be read as mere flattery of the ambitions of lords who longed for the glories of Caesar and other ancient leaders, but rather as the expression of a sincere belief that the Roman Empire was the most complete fulfillment of the harmony of orders (concordia ordinum). ${ }^{26}$

\section{Vernacular Policy, or Vernacular Humanism}

At the end of the 1420s, Filippo Maria Visconti implemented two administrative measures that would have important political and cultural consequences. One was the reorganization of the Ducal Library of Pavia, established by Filippo Maria's father, Duke Gian Galeazzo Visconti, from the library of Francesco da Carrara, Lord of Padua, seized in 1388, which

25 See N. Rubinstein, "Le dottrine politiche nel Rinascimento", in Il Rinascimento. Interpretazioni e problemi (Roma - Bari, 1979) 183-237, at 219; Crevatin 1982 (as in n. 18), 283; Canfora 2001 (as in n. 18), 43. On the political implications of this controversy, see H. Baron, The Crisis of the Early Italian Renaissance. Civic Humanism and Republican Liberty in an Age of Classicism and Tyranny (Princeton, NJ, 1966²), 66-68; J.W. Oppel, "Peace vs. Liberty in the Quattrocento. Poggio, Guarino and the Scipio-Caesar Controversy", The Journal of Medieval and Renaissance Studies 4 (1974), 221-265. On Caesarism at the court of the Este, see M. Pade, "Guarino and Caesar at the Court of the Este", in Ead., L. Waage Petersen, D. Quarta (ed.), La corte di Ferrara e il suo mecenatismo (1441-1598). Atti del Convegno internazionale (Copenaghen, maggio 1987) (Modena, 1990), 71-91.

26 See Brown 1981 (as in n. 18), 325; A. Asor Rosa (ed.), Letteratura italiana, vol. 1: Il letterato e le istituzioni (Torino, 1982), 249; H. Schadee, "The First Vernacular Caesar. Pier Candido Decembrio's Translation for Íñigo d'Ávalos with Editions and Translations of Both Prologues", Viator 46 (2015), 277-304, at 286-287. For an interpretation of Baron's civic humanism, see J. Hankins, “The 'Baron Thesis' after Forty Years and Some Recent Studies of Leonardo Bruni”, Journal of the History of Ideas 56 (1995), 309-338; L. Gualdo Rosa, "L'umanesimo di Leonardo Bruni. Revisionismo 'made in U.S.A.", Schede umanistiche 19 (2005), 25-37. On 'courtly humanism', see W.L. Gundersheimer, Ferrara. The Style of a Renaissance Despotism (Princeton, NJ, 1973); B.G. Kohl, "Political Attitudes of North Italian Humanists in the Late Trecento", Studies in Medieval Culture 4 (1974), 418-427. 
famously included Petrarch's books. ${ }^{27}$ This reorganization resulted in the first known inventory of the Visconti Library, the Consignatio librorum (1426), which includes 988 entries, 90 of which are in French and only 52 in Italian. ${ }^{28}$ The second measure was the 1427 adoption of the vernacular as the official language of the ducal chancellery. ${ }^{29}$ The next step for the duke of Milan was to encourage the use of the vernacular by the humanists of his court, so that their works could give the Ducal Library a radically new imprint.

The first works translated for Filippo Maria Visconti were Suetonius's Lives of the Caesars and the Historia Augusta, whose dedication copy is the manuscript now Paris, Bibliothèque nationale de France, ms. it. 131, transcribed by Pier Candido Decembrio's brother Angelo in 1431 and sumptuously illuminated by an anonymous illuminator known for his work on this manuscript as the Master of the Vitae imperatorum. ${ }^{30}$ The translation is attributed to the humanist Antonio da Rho by a note written on a flyleaf of another copy, now Città del Vaticano, Biblioteca Apostolica Vaticana, ms. Urb. lat. 437, but this attribution is highly doubtful, as

27 For a general overview on the Visconti-Sforza library, see F. Petrucci Nardelli, "La biblioteca Visconteo Sforzesca. Ubicazione e disposizione del materiale librario", La Bibliofilia 97 (1995), 21-33; U. Rozzo, "La biblioteca Viscontea e Sforzesca", in G. Arbizzoni, C. Bianca, M. Peruzzi (ed.), Principi e signori. Le biblioteche nella seconda metà del Quattrocento. Atti del Convegno di Urbino (5-6 giugno 2008) (Urbino, 2010), 338; M.G. Albertini Ottolenghi, "Note sulla Biblioteca dei Visconti e degli Sforza nel Castello di Pavia", Bollettino della Società Pavese di Storia Patria, n.s., 113 (2013), 35-68.

28 On the inventories of the Visconti-Sforza library from 1426 to 1490 , see É. Pellegrin, La Bibliothèque des Visconti et des Sforza, ducs de Milan au XVe siècle (Paris, 1955) and Supplément (Florence - Paris, 1969); A.G. Cavagna, "'Il libro desquadernato: la carta rosechata da rati'. Due nuovi inventari della libreria visconteo-sforzesca", Bollettino della Società Pavese di Storia Patria, n.s., 88 (1989), 29-97; E. Fumagalli, "Appunti sulla biblioteca dei Visconti e degli Sforza nel castello di Pavia" and S. Cerrini, "Libri e vicende di una famiglia di castellani a Pavia nella seconda metà del Quattrocento", Studi petrarcheschi, n.s., 7 (1990), 93-211 and 329-409; Ead., "Libri dei Visconti-Sforza. Schede per una nuova edizione degli inventari" and M.G. Albertini Ottolenghi, "La biblioteca dei Visconti e degli Sforza. Gli inventari del 1488 e del 1490”, Studi Petrarcheschi, n.s., 8 (1991), 239-81 and 1-238.

29 On the use of the vernacular in the ducal chancellery at the time of Filippo Maria Visconti, see M. Vitale, La lingua volgare della cancelleria visconteo-sforzesca nel Quattrocento (Varese - Milano, 1953).

30 On the Master of the Vitae imperatorum, see A. Melograni, “Appunti di miniatura lombarda. Ricerche sul Maestro delle Vitae Imperatorum", Storia dell'Arte 70 (1990), 273314; F. Lollini, "Maestro delle Vitae imperatorum", in M. Bollati (ed.), Dizionario biografico dei miniatori italiani. Secoli IX-XVI (Milano, 2004), 587-589. 
the note is written by a much later hand. ${ }^{31}$ Given that the dedication copy was transcribed by Angelo Decembrio, it is possible that the translator was his brother Pier Candido, who, as we will see below, was responsible for other vernacular translations commissioned by Filippo Maria Visconti in the late 1430s. ${ }^{32}$ However, the choice of the lives of the Roman emperors reveals not only the duke of Milan's ideological attitudes and literary tastes, but also his desire to establish a section of vernacular translations of ancient histories in his library in Pavia. ${ }^{33}$

This is confirmed by three manuscripts executed in 1432 for the Ducal Library, now Oxford, Bodleian Library, ms. Digby 224 and Paris, Bibliothèque nationale de France, ms. it. 118 and 119, containing respectively the first, third, and fourth decades of Livy's Historiae translated into the vernacular. ${ }^{34}$ It is interesting that these manuscripts contain a Florentine vernacular translation of Livy dating from the fourteenth century rather than a new Milanese translation, a circumstance that is perfectly consistent with Pier Candido Decembrio's account with respect both to Filippo Maria's passion for Livy and to the fact that he used to listen to ancient histories "whether in their established vernacular versions, or as translated by humanists from Latin," as if for the duke there was no difference between Florentine and Milanese vernacular literature. ${ }^{35}$

Another aspect of Pier Candido Decembrio's portrait of Filippo Maria Visconti as a reader is his passion for French chansons de gestes. ${ }^{36}$ At an

31 This manuscript is described in C. Stornajolo (ed.), Codices Urbinates Latini. vol. 1: Codices 1-500 (Romae, 1902), 436-440.

32 The attribution to Antonio da Rho has never been questioned, but no evidence has been put forward so far, apart from the note in the Vatican manuscript, see Zaggia 1993 (as in n. 3), 198.

33 The Consignatio librorum lists vernacular translations of Valerius Maximus (no. 245), as well as of Lucan and Sallustius (no. 896), see Zaggia 1993 (as in n. 3), 175 and n. 44.

34 See Zaggia 1993 (as in n. 3), 190-191.

35 On Filippo Maria Visconti's 'curiosity' for Florentine literature, see C. Dionisotti, "Fortuna del Petrarca nel Quattrocento", Italia medioevale e umanistica 17 (1974), 61-113, at 79 .

36 As of 1426, the Ducal Library hosted an extensive collection of chansons de gestes, such as the Anseis de Cartage (no. 401 of the Consignatio librorum), the Chevalerie Vivien and the Aliscans (no. 413), the Huon d'Auvergne (no. 774), Aimon de Varennes's Florimont (no. 777), as well as Guillaume de Lorris and Jean de Meun's Roman de la Rose (no. 900), prose versions of the Queste du Saint Graal and of the Mort Artu (no. 908 and 916), Guillaume Tirel's Viandier (no. 917), the Lancelot (no. 948), the Tristan (no. 952), and another unspecified novel of the Round Table cycle (no. 898). 
uncertain date, but likely in the 1430s, the humanist Galasso da Correggio dedicated to Filippo Maria a Latin Historia Angliae (History of Anglia) the dedication copy is now Paris, Bibliothèque nationale de France, ms. lat. $6041 \mathrm{D}$ - that is regarded as an attempt to reconcile the demands of a traditional work of history with the fabulous material of the Breton cycle, contemptuously defined by Decembrio as "tall tales". 37 If Galasso's Historia Angliae can be read as a courtly product in the strict sense, that is, a work aimed exclusively at gratifying the personal tastes of the duke of Milan, it is true at the same time that this work is a good example of the duke's idea of literary studies. In a period such as the early fifteenth century, in which humanists wrote almost exclusively or at least preferably in Latin, endeavoring to conform both form and content of their works to the canons of classical Latin literature, Filippo Maria Visconti 'forced' the humanists of his court to write in the vernacular, or, as in Galasso da Correggio's work, to write in Latin on a subject conventionally linked to vernacular literature and far inferior to humanistic studies, but always falling into the duke's favorite literary genre, historiography.

Filippo Maria Visconti entrusted the task of completing the section of vernacular historical works in the Ducal Library to Pier Candido Decembrio, who was the duke's secretary in addition to being the most prominent humanist at his court. In 1438, Decembrio finished the translation of three works: Caesar's De bello Gallico, Curtius Rufus's Historia Alexandri Magni, and Polybius's De primo bello Punico (from Leonardo Bruni's Latin translation). ${ }^{38}$ Apparently, the choice of the works that would be translated followed a chronological criterion: as the Ducal Library already hosted vernacular translations of Livy's histories and Suetonius's Lives of the Caesars, Decembrio sought to fill the chronological gaps between these texts. Thus he chose to translate Polybius's De primo bello Punico and Caesar's commentaries, as Livy's surviving books omit the First Pu-

37 On Galasso da Correggio's Historia Angliae, see A. Malanca, "Le armi e le lettere. Galasso da Correggio autore dell'Historia Angliae", Italia medioevale e umanistica 48 (2007), 1-57.

38 See Zaggia 1993 (as in n. 3), 199-219, 323-340; M. Pade, "Curzio e Plutarco nell'Istoria d'Alexandro Magno. Volgarizzamento e compilazione in un testo di Pier Candido Decembrio", Studi umanistici piceni 18 (1998), 101-113; M. Materni, "Tracce plutarchee fra due Penisole nella scia di Decembrio. Umanesimi e umanesimi volgari”, Revista de literatura medieval 26 (2014), 245-297; Schadee 2015 (as in n. 26); P. Ponzù Donato (ed.), Pier Candido Decembrio, Volgarizzamento del Corpus Caesarianum (Firenze, 2017); Id., "MS Varia 131 of the Biblioteca Reale di Torino and Decembrio's Translation of Curtius Rufus”, Translat Library 1.4 (2019) (doi: 10.7275/7fre-3a35). 
nic War, the Gallic War, and the Roman Civil War. After translating De bello Gallico, Decembrio started work on Caesar's De bello civili and on the other commentaries of the Corpus Caesarianum, but this translation would never be completed, breaking off with the Bellum Africum, the penultimate commentary of the Corpus. Moreover, Decembrio added to his translations of Caesar's commentaries and Curtius Rufus's Historia Alexandri Magni a vernacular Comparatione di Caio Iulio Cesare imperatore maximo e d'Alexandro Magno (Comparison between Gaius Julius Caesar, the Greatest Emperor, and Alexander the Great), a short discussion of Caesar and Alexander the Great in which Decembrio, taking Plutarch's method of comparison ( $\sigma 0 ́ \gamma \kappa \rho ı \sigma \varsigma)$ as a model, argued for the superiority of Caesar. ${ }^{39}$

However, if Decembrio's position appears to be in line with Visconti's Caesarism, neither the Comparatione nor the prefaces to the translation of Caesar's commentaries contain explicit references to Visconti's policy or propaganda claims. This is due in part to the fact that, where Guarino Veronese and Poggio Bracciolini compared Caesar to Scipio Africanus, that is, an imperial leader to a republican leader, Decembrio compares Caesar to Alexander the Great, that is, a model of princely behavior to another model of princely behavior. Consequently, Decembrio does not address the ideological implications of the contrast between Caesar's princely rule and the republican regime, as was inevitable in the controversy between Poggio and Guarino. ${ }^{40}$ Rather, he (like Guarino) claims for Caesar both military and literary glory, attributing to him, and not to Suetonius or Julius Celsus, the authorship of the first seven books of the De bello Gallico and the entire De bello civili. Besides being an excellent war leader, Caesar was an excellent writer, Decembrio continues, and the Roman emperors of the Julio-Claudian dynasty were literary men as well. It is evident that, in Decembrio's view, Caesar embodied the perfect rela-

39 On Plutarch's бó $\gamma \kappa \rho ı เ \varsigma$, , see D.H.J. Larmour, "Making Parallels. Synkrisis and Plutarch's Themistocles and Camillus", in Aufstieg und Niedergang der römischen Welt 2.33.6 (1992), 4154-4200; T. Duff, Plutarch's Lives. Exploring Virtue and Vice (Oxford, 1999), 243-286.

40 See Zaggia 1993 (as in n. 3), 205; M. Pade, The Reception of Plutarch's Lives in Fifteenth-Century Italy, vol. 1 (Copenhagen, 2007), 251-252. 
tionship between letters and arms, an ideal to which Filippo Maria Visconti himself aspired. ${ }^{41}$

In 1436 - the same year in which Decembrio likely finished writing his panegyric in praise of Milan - Leonardo Bruni composed his ver-nacular lives of Dante and Petrarch, an anti-imperial and republican reading of the two illustrious Florentine writers that suggests that Bruni intended these works as an indirect reply to Visconti policy, if not to Decembrio's panegyric. ${ }^{42}$

While Bruni claimed the 'Florentinity' of Dante and Petrarch, Filippo Maria Visconti commissioned from the humanists of his court several commentaries on Dante's Comedy and Petrarch's Canzoniere. If there is no evidence of a written commentary on Dante's poem by Marziano da Tortona, ${ }^{43}$ Guiniforte Barzizza's commentary on the Inferno (1438) has survived. The dedication copy of this commentary, with illuminations by the Master of the Vitae imperatorum, is now Paris, Bibliothèque nationale de France, ms. it. 2017, but in the nineteenth century Giuseppe Zaccheroni, who first published the text in 1838, extracted from it twelve folios, now Imola, Biblioteca Comunale, ms. 32, while other fragments containing illuminations are in private hands. ${ }^{44}$

41 See A. Tissoni Benvenuti, "Le armi e le lettere nell'educazione del signore nelle corti padane del Quattrocento", Mélanges de l'École Française de Rome. Moyen Age / Temps modernes 99 (1987), 435-446; Schadee 2015 (as in n. 26), 287-289; Ponzù Donato 2017 (as in n. 38), LVI.

42 See A. Lanza, Firenze contro Milano. Gli intellettuali fiorentini nelle guerre con $i$ Visconti (1390-1440) (Anzio, 1991), 147-153. On Bruni's lives, see P. Trovato, "Dai Dialogi ad Petrum Histrum alle Vite di Dante e del Petrarca. Appunti su Leonardo Bruni e la tradizione trecentesca", Studi petrarcheschi, n.s., 2 (1985), 263-284; L. Gualdo Rosa, "Leonardo Bruni e le sue 'vite parallele' di Dante e del Petrarca", Lettere italiane 47.3 (1995), 386-401; G. Tanturli, “Dante, Firenze, Leonardo Bruni”, Studi danteschi 66 (2001), 179-203; G. Ianziti, "From Praise to Prose. Leonardo Bruni's Lives of the Poets", I Tatti Studies 10 (2005), 127-148; Schadee 2018 (as in n. 23), 19-23.

43 On Marziano Rampini da Tortona (d. before 1425), see G. Varanini, "Marziano da Tortona", in Enciclopedia dantesca, vol. 3 (Roma, 1970), 850-851; U. Rozzo, "Ritratto di Marziano da Tortona", in Marziano da Tortona e $i$ tarocchi. Catalogo della mostra (Tortona, 30 ottobre-14 novembre 1982) (Tortona, 1982), 2-17.

44 For an overview on Guiniforte Barzizza and his commentary on Dante's Inferno, see G. Ferraù, "Il commento all' Inferno di Guiniforte Barzizza”, in A. Borraro, P. Borraro (ed.), Dante nel pensiero e nella esegesi dei secoli XIV e XV. Atti del $3^{\circ}$ Congresso nazionale di studi danteschi (Melfi, 27 settembre-2 ottobre 1970) (Firenze, 1975), 357-373; Zaggia 1993 (as in n. 3), 343-349; Id., "Guiniforte Barzizza e il suo commento dantesco", in C. Villa, F. Lo Monaco (ed.), Maestri e traduttori bergamaschi fra Medioevo e Rinascimento (Bergamo, 1998), 119-151 (esp. 136-142, 147-159); S. Bellomo, Dizionario dei 
Petrarch's Canzoniere was commented on by the Sienese physician and astrologer Pietro Lapini da Montalcino, known as Illicino, but his commentary is now lost. ${ }^{45}$ Guiniforte Barzizza also wrote a commentary on Petrarch's poems that was intended to provide a historical and textual interpretation, in contrast to Lapini's allegorical interpretation, but only the dedicatory letter and the commentary on Voi ch'ascoltate in rime sparse il suono $(R V F 1)$ survive. $^{46}$ In 1438 , Pier Candido Decembrio composed a commentary on Petrarch's sonnets, which is lost, and he was likely the author of a vernacular life of Petrarch long attributed to Antonio da Tempo. ${ }^{47}$ Another humanist who commented on Petrarch for Filippo Maria Visconti was Francesco Filelfo, whose commentary survives but is incomplete, the last poem commented on being $R V F 136 .{ }^{48}$

In the prefatory letters to his commentaries on Dante's Inferno and Petrarch's Canzoniere, Guiniforte Barzizza insists on his unfamiliarity with vernacular literature, stating that if Filippo Maria Visconti had ordered him to deal with a subject more suited to humanistic studies or

commentatori danteschi. L'esegesi della Commedia da Iacopo Alighieri a Nidobeato (Firenze, 2004), 134-139.

45 Pietro Lapini's son, Bernardo, later wrote a commentary on Petrarch's Trionfi, see C. Vasoli, "Bernardo da Siena detto Illicino", in Dizionario biografico degli italiani [henceforth $D B I$ ], vol. 9 (Roma, 1967), 290-291.

46 The only known manuscript is now Paris, Bibliothèque nationale de France, ms. nouv. acq. lat. 1819, see Zaggia 1993 (as in n. 3), 353-354. The surviving text was edited and illustrated in F. Ruggiero, "Il commento di Guiniforte Barzizza a Voi ch'ascoltate. Edizione, cronologia, proposte", in L. Geri, M. Grimaldi (ed.), La lirica italiana dalle origini al Rinascimento (Roma, 2017), 105-125.

47 See G. Mezzanotte, "P.C. Decembrio e la Vita del Petrarca attribuita ad Antonio da Tempo”, Studi Petrarcheschi, n.s., 1 (1984), 211-224, esp. 211-216; Zaggia 1993 (as in n. 3), 350-353.

48 See E. Raimondi, "Francesco Filelfo interprete del Canzoniere", Studi petrarcheschi 3 (1950), 143-164; Dionisotti 1974 (as in n. 35), 78-88; R. Bessi, "Sul commento di Francesco Filelfo ai Rerum vulgarium fragmenta", Quaderni petrarcheschi 4 (1987), 229-270; Ead., "Filelfo commenta Petrarca", in B. Bentivogli, G. Gorni (ed.), Il commento al testo lirico. Atti del Convegno (Pavia, 25-26 ottobre 1990) (Ferrara, 1995) [= Schifanoia 15-16], 91-98; A. Tissoni Benvenuti, "Il commento per la corte", in Intorno al testo. Tipologie del corredo esegetico e soluzioni editoriali. Atti del convegno (Urbino, 1-3 ottobre 2001) (Roma, 2003), 195-221; L. Marcozzi, "Tra Da Tempo, Filelfo e Barzizza. Biografia sentimentale e allegoria morale nei commenti quattrocenteschi al Canzoniere di Petrarca", in B. Porcelli (ed.), Petrarca volgare e la sua fortuna sino al Cinquecento, Italianistica 33.2 (2004), 163-177; L. Verrelli, "Il proemio del Commento di Francesco Filelfo, ai Rerum vulgarium fragmenta. Ipotesi preliminari”, Medioevo e Rinascimento 28 (2014), 95-125. The editio princeps of Filelfo's commentary was printed together with Bernardo Lapini's commentary on the Trionfi (Bologna, Annibale Malpighi, 1475-1476, IGI 7543 and 7529; BMC VI 811). 
more in keeping with his education, he could have met the duke's expectations far better. ${ }^{49}$ Pier Candido Decembrio made a similar remark in an undated letter to Simonino Ghilini, a favorite of Filippo Maria Visconti and the person who had the task of consigning to the duke Decembrio's translation of Curtius Rufus's Historia Alexandri Magni:

I admit that I would value my profession very little if I remembered or magnified those works that we translated into our mother tongue and circulated among the common people, which, although they have been praised and brought to light by many, have always had less authority for me, and I have never been led by the number of volumes or by the delight in the common people to compare them to this very cultured genre of writing [= Latin writing].$^{50}$

Yet in an earlier letter to Ghilini, Decembrio had stated that his translation of Curtius Rufus was "a work worthy of [the duke's] majesty", revealing some pride in having accomplished the duke's commission. ${ }^{51}$

In a letter to Francesco Pizolpasso, archbishop of Milan, dating to the late summer of 1438, Pier Candido Decembrio wrote:

You have repeatedly expressed concern about the fact that I have dedicated myself to translating Latin books into [our] mother tongue by order of my prince, as I learned from your messages. So you want me to turn my commitment and my attention to better occupations. You are indeed right, but one must submit to the times, and since you are keen to know which works in particular I have

49 See Ruggiero 2017 (as in n. 46), 123: "Se cossa me fusse imposta più pertenente a la professione di studii mei, o più conforme a la institucione di mia vita, credo ch'io puoterebbe satisfare vie meglio a vostra expectacione."

50 "Fateor me levius admodum consulere rebus meis si ea opera repeterem aut magnifacerem, quae in vulgus emanarunt et quae a nobis in maternam linguam traducta sunt; quae quamquam a multis commendata sint et in lucem edita, minus tamen auctoritatis apud me semper habuere, nec numero librorum aut vulgi libidine adduci potui, ut ea cum hoc humanissimo scribendi genere conferrem," see V. Zaccaria, "Sulle opere di Pier Candido Decembrio", Rinascimento 7 (1956), 13-74, at 26-27 (on the dating of this letter, see 47 and 59 n. 1); Zaggia 1993 (as in n. 3), 202. The translation is mine.

51 "Scribo etiam Iacopo breviter, cui una tibique transmitto id modicum Curtii quod traductum est, cum ulterius progredi nequiverim monitus ab eo ut commentarios C. Caesaris prius exararem, quod facio dietim, et ex hoc principio quae secutura sunt cognoscere poteritis. Demum si principi gratum fuerit, residuum dato tempore conficiam. Unum rogo, ut praefato principi librum offerendo me etiam reddatis recommissum, nam opus est, ni fallor, sua dignum celsitudine," see Zaggia 1993 (as in n. 3), 321, n. 195. 
translated, I tell you that I have translated into [our] mother tongue all the books of Quintus Curtius, then Julius Caesar's commentaries, and finally Polybius's [First] Punic War; moreover, I composed a not inelegant explanation of Petrarch's sonnets at my friends' request, which I satisfy now so that I can spend much more time in studies worthy [of my profession]. ${ }^{52}$

So Decembrio considered his vernacular translations and his commentary on Petrarch a waste of time, or at least this is what he suggests in this letter. As Decembrio writes, his translations of Curtius Rufus and Caesar enjoyed some popularity, yielding numerous manuscripts (42 and 15 of which respectively survive), while his commentary on Petrarch was popular enough to be remembered twenty-five years later by the humanist Federico Galli. ${ }^{53}$ Moreover, given Decembrio's work on the Latin text of Caesar's commentaries before translating them into the vernacular - a work that could be compared to some extent to a critical edition - it is unlikely that he had so little consideration for the duke's commissions. ${ }^{54}$ What is striking here, however, is the resigned statement "one must submit to the times" ("tempori parendum est"), that is, 'so goes the world', a statement that could also be read as an expression of cynical condescension toward the literary fashion of his time. ${ }^{55}$

Barzizza and Decembrio's attitude toward vernacular literature and translation should be interpreted as an inability to adapt themselves to the cultural policy imposed by Filippo Maria Visconti, who, unlike the hu-

52 See R. Fubini, "Tra Umanesimo e concili. Note e giunte a una pubblicazione recente su Francesco Pizolpasso (1370 c.-1443)", Studi medievali 3.7 (1966), 323-370, at 362: "Condoluisti de studio meo pluries in vertendis latinis libris in maternam linguam, mandato principis mei, ut ex nuntiis tuis sensi. Velles enim ut ad meliora studium curamque converterem. Bene arguis [augeris Mss.] profecto, sed tempori parendum est, et quia nosse cupis quae opera potissimum transtulerim, scito omnes libros Quinti Curcii, dein Commentarios Iulii Caesaris, postremum Polibii De bello Punico a me in maternum sermonem redactum esse; praeterea in sonitiis Petrarcae expositionem non inelegantem a me editam amicorum precibus, quibus ita faveo, ut plurimum tamen temporis impendeam ad studia digniora." The translation is mine.

53 Galli wrote: "Memini te significasse talem vitam [scil., Petrarchae] copiosissime collegisse commentumque super cantilenas edidisse," see Zaccaria 1956 (as in n. 50), 57 n. 1; Zaggia 1993 (as in n. 3), 349 n. 305. On Galli, see G. Nonni, "Galli Federico", in DBI, vol. 51 (Roma, 1998), 617-619.

54 See P. Ponzù Donato, "Pier Candido Decembrio editore di Cesare", Italia medioevale e umanistica 59 (2018), 165-191.

55 See Zaggia 1993 (as in n. 3), 333. Decembrio's statement recalls Publius Syrus's proverb: "honeste servit, qui succumbit tempori” (Pub. Syr. 256). 
manists, preferred the vernacular language to Latin, not because of his personal tastes as a reader or his poor culture, but rather because he was aware that promoting vernacular literature could have a more profound political impact than promoting Latin and Greek literature. At the same time, Decembrio's choice to use Leonardo Bruni's Latin translation of Polybius's De primo bello Punico for his vernacular translation, regardless of personal rivalries between the two humanists, has evident ideological consequences, not only because the work ends precisely with the Roman conquest of the city of Milan, but also because Decembrio presents his vernacular translation as parallel to Bruni's Latin translation. ${ }^{56}$

It was Filippo Maria Visconti, and not the humanists in his service, who promoted vernacular humanism in Lombardy, with the aim of taking over from Florence the role of driving force of the Italian language and Italian literature. ${ }^{57}$ In Visconti's view, literary appropriation of the masterpieces of Florentine literature (the commentaries on Dante and Petrarch) went hand in hand with appropriation of Rome's glorious past (the vernacular translation of ancient histories), making Milanese vernacular humanism the true heir of imperial Roman literature. ${ }^{58}$

56 For an overview on humanists and the vernacular, see M. Tavoni, "Lorenzo Valla e il volgare", Medioevo e Umanesimo 59 (1986), 199-216; R. Bessi, Umanesimo volgare. Studi di letteratura fra Tre e Quattrocento (Firenze, 2004); G. Tanturli, "Umanesimo civile, umanesimo volgare. I sonetti di Coluccio Salutati", in M. Bendinelli Predelli (ed.), Firenze alla vigilia del Rinascimento. Antonio Pucci e $i$ suoi contemporanei. Atti del convegno di Montreal (22-23 ottobre 2004) (Montreal, 2006), 333-378; A. Cornish, Vernacular Translation in Dante's Italy. Illiterate Literature (Cambridge, 2011); B.J. Maxson, "This Sort of Men'. The Vernacular and the Humanist Movement in FifteenthCentury Florence", I Tatti Studies in the Italian Renaissance 16.1/2 (2013), 257-271; Rizzi 2017 (as in n. 5), 75-89.

57 In the prefatory letter, Decembrio writes: "la presente opra che da Polibio per la magior parte scripta si ritrova, di latina in materna lingua da me serà traducta, sì come da l'Aretino di greca in prima latina facta fue" (I quote from Madrid, Biblioteca Nacional de España, ms. 10301, f. 1v). On the rivalry between Decembrio and Bruni, see V. Zaccaria, "Pier Candido Decembrio e Leonardo Bruni", Studi Medievali 3.8 (1967), 504-554; P. Viti, Leonardo Bruni e Firenze. Studi sulle lettere pubbliche e private (Roma, 1992), 140-142, 179-180. On Bruni's translation, see G. Ianziti, "Between Livy and Polybius. Leonardo Bruni on the First Punic War", Memoirs of the American Academy in Rome 51 (2006), 173197.

58 This is evident, for example, in the dedicatory letter of Decembrio's translation of Polybius, whose dedicatee, ducal chamberlain Iacopo d'Abbiate, is compared to Maecenas, or in a Latin poem dedicated by Decembrio to Filippo Maria Visconti: "Sic tua Caesareos superet fortuna nepotes / aequa Philippeo sit tua fama duci: / deprecor Ausonios summas redimitus honores / astriferosque petat serior umbra polos," see Zaggia 1993 (as in n. 3), 338-340. 


\section{Between Dante and Caesar: Guiniforte Barzizza's Commentary on Dante's Inferno}

Some passages of Guiniforte Barzizza's commentary on Dante's Inferno offer further evidence confirming the hypothesis that Filippo Maria Visconti in the late 1430s was more adept at waging the cold war of literature than the hot war of arms against Florence.

Commenting on Inf. 6.58-76, where Ciacco, at Dante's request, reveals his prophecy of the fate of Florence, Barzizza writes:

I do not want to tell the story [of the division between White and Black Guelphs in Florence] in detail, because this is not necessary to explain the text to the same extent as it would be bound to renew the ancient divisions in the heart of that people and multiply too many evils. My nature does not allow me to deal with this topic, nor would our very clement lord and illustrious duke permit it, who, at the present time, showing his usual clemency and forgiving all hatred, outrage, and offense, has granted his benevolence to the aforesaid community of Florence; he is happy to see it at peace and thinks of giving it abundant favors so that it can refresh itself from the damage it has suffered and completely free itself from any fear of that perpetual slavery in which it had voluntarily enveloped itself in past years. 59

This passage is important not only because it confirms the dating of Barzizza's commentary to 1438 , the year in which a peace was signed between Milan and Florence, ${ }^{60}$ but also because it is a perfect example of Visconti's Caesarism. First, it is thanks to Filippo Maria Visconti's clemency - the same virtue as Caesar - that the citizens of Florence can live in peace, repair the damage of the war, and free themselves from the fear of

59 "Non voglio distintamente recitar la hystoria, peroché questo non è tanto necessario ad dechiaracion del testo quanto serebbe sufficiente ad renovar le antiche parcialitati nel cuor di quel populo et multiplicar mal assai. Alla qual cossa ch'io metta lo ingegno mio né mia natura lo sostiene et il clementissimo signor nostro illustrissimo duca non lo permetterebbe, el quale, nel tempo presente, usando di consueta sua clemencia, remettendo ogni odio, iniuria et offensione, con benignità concede alla ditta comunità de Fiorença; ama de vederla in reposo et pensa in che modo a $\cdot$ llei doni copioso favore sì che la possa restorarsi de suoi danni et in tutto liberarsi da ogni timor di quella perpetua servitù in la quale ne li anni passati voluntariamente se era involuppata" (I quote from Paris, Bibliothèque nationale de France, ms. it. 2017, f. 77r-v). The translation is mine.

60 See Cognasso 1955 (as in n. 7), 324-327. On the dating of Barzizza's commentary, see Ferraù 1975 (as in n. 44), 358-359. 
losing freedom, a fear that, as Barzizza points out, originates in the attitude of the Florentines themselves, who chose to fight Visconti rather than surrender to his will. ${ }^{61}$ A specific political message also emerges from Barzizza's words: Filippo Maria Visconti does not want the commentary to emphasize Dante's aversion to Florence, in order to avoid rekindling ancient divisions in the hearts of the Florentines. The duke of Milan, therefore, has imposed on Barzizza not only the themes to be treated but also the way in which to treat them so as not to offend the sensibilities of the Florentines, with whom he is now at peace, at least in appearance.

The same attitude is evident in the passage in which Barzizza comments on Inf. 15.73-78, where Brunetto Latini evokes the origins of Florence, expressing the sinister wish that the Florentines (called "the beasts of Fiesole") devour each other:

[Dante] refers to the people of Florence, who descended from the inhabitants of Fiesole. Based on this information, some claim that after the Romans destroyed the city of Fiesole, which deserved this [punishment] for the wickedness [of its inhabitants], the inhabitants of Fiesole built the city of Florence no more than four or five miles away from there, and those who had been banished from Rome rushed to live in that place. Others say otherwise. It is not my intention to rack my brains over stories constructed at random. The author suggests that Dante would have drawn upon himself the hatred of the people of Florence for acting honestly, and as before the time when according to his fiction he descended to hell and before the time when he wrote this work, the people of Florence were divided into Black and White factions, he spoke for the sake of the common good. So it is said that, after having fallen under suspicion by those who ruled the state, it was necessary for him to run away from Florence. ${ }^{62}$

61 Pier Candido Decembrio insists on Visconti's clemency as well, see Ianziti, Zaggia 2019 (as in n. 1), 44-47; Hankins 2019 (as in n. 5), 142.

62 "Del populo de Firença parla, el qual discese da Fiesuli. Per noticia de la qual cossa dicono alchuni che da' Romani essendo disfatta la cità de Fiesuli cussì meritando la lor malignitade edificaron poi Fiesulani non longi da ivi quatro o cinque millia la cità de Firença, ove anchora concorseno ad habitare bandegiati di Roma. Altri dicono in altro modo. Mia intencion non è de rumpermi 'l capo in hystorie fatte ad beneplacitum. Che per ben far di Dante sia per farsili nemico quel populo de Firença introduce l'autore, però che dietro al tempo nel quale secundo sua ficcione il discese a l'inferno et nanti el tempo che 'l 
As in the previous passage, here too we see Barzizza's (and Filippo Maria Visconti's) desire not to emphasize Dante's invective against Florence, albeit with different results. Barzizza tries to contextualize Dante's words to justify his feelings against his hometown, suggesting that Dante's hatred of Florence was due to the fact that he was aware of having acted honestly and for the sake of his fellow citizens, and that it was his own fellow citizens who forced him into exile. In making this remark, however, Barzizza goes against Visconti's order not to recall the internal divisions of the people of Florence. Moreover, he follows the account of Florence's origin reported by Pier Candido Decembrio and Lorenzo Valla. ${ }^{63}$

Thus, Visconti's ideology and propaganda override his efforts at diplomatic tact, so that Barzizza does not miss the opportunity to highlight Dante's reference to Caesar as one of the "great souls" ("spiriti magni") in the fourth canto of the Inferno (v. 123), stating:

[Caesar] subdued the very warlike peoples of Gaul, the indomitable peoples of Germany, the very strong peoples of England, the brave peoples of Spain, the fierce peoples of Africa, the countless peoples of Asia. None of the four parts of the world, eastern, southern, western, and northern, managed to resist Caesar's impetus [...] Provoked by the many insults of his emulators and detractors, he conquered those who had conquered the world and took the reins of Italy, and there, after having pacified the Roman state by treating with supreme clemency his worst enemies, honoring virtuous men and rewarding those who had well deserved [reward], and striving with the utmost care to restore the Republic amid the damage it had received, we see him assassinated by Decius Brutus and Cassius and other conspirators in a conspiracy in the Senate. ${ }^{64}$

scrisse questa opra essendo 'l populo de Firença venuto ad division de parte negra et biancha parlava lui per lo ben comune. Unde dicessi che caduto in sospicione de quelli che reggevano 'l stato convenne che 'l si partisse da Firença" (I quote from Paris, Bibliothèque nationale de France, ms. it. 2017, f. 180v). The translation is mine.

63 See Ferraù 1975 (as in n. 44), 370.

64 "Subiugò lui li bellicosissimi populi di Gallia, li indomiti de Germania, li fortissimi di Angliterra, li animosi di Spagnia, feroci de Affrica, innumerabili de Asia. Nisuna de le quatro regioni del mundo, orientale, meridionale, occidentale et septentrionale potté resister a l'impeto di Cesare. [...] Per molte iniurie provocato lui ad indignatione da' suoi emuli et detractori, vincitore di quelli che havevano vinto el mundo, misse freno ad Italia, in la quale, pacificato che hebbe lo stato di Roma usando di summa clementia verso li capitalissimi nemici, honorando li virtuosi, premiando quelli che havevano ben meritato, studiando 
According to Barzizza, who echoes Guarino Veronese's arguments against Poggio Bracciolini, Caesar was an enlightened and clement ruler, the restorer of the Roman Republic, and not a tyrant who repressed civil liberties, as Florentine propaganda claimed. ${ }^{65}$ Consistently, Barzizza praises imperial rule, declaring in his commentary on Inf. 2.22 that "some passionately claim that empire is not fair, the same people who tyrannize in their community under a false name of freedom."

This statement, which almost literally quotes Antonio Loschi's formula, clearly alludes to Florence, showing that even if the duke of Milan apparently flaunted his peaceful intentions toward his eternal rival, at the same time the humanists of his court did not hesitate to declare the superiority of the empire and the greatness of Caesar, reviving the themes of Gian Galeazzo Visconti's propaganda. Although the political and military struggle between Milan and Florence seemed to have ceased, at least for the moment, the ideological opposition between Caesarism and republicanism continued to be heated. Therefore, if the Florentine humanists proudly proclaimed Florence's republican ancestry, bypassing Caesar and presenting Florence as the heir of the Roman Republic, Barzizza claimed for the Visconti dynasty direct descent from Aeneas and membership in the gens Iulia, avowing in his commentary on Inf. 2.16-21:

God, thanks to his foreknowledge, considered the great result that was to come from Aeneas, who in the empyrean sky was chosen as the father of nourishing Rome and so on. On the other hand, it should not seem inappropriate to us today that God favored Aeneas, because he considered the great result that was to come from him, that is, the illustrious and excellent house of the Visconti, who later gave the world many illustrious princes and valiant leaders and our most serene duke of Milan Filippo Maria, governor of the aforesaid

con summa diligentia de restaurar la Repubblica nei danni che la haveva receputi, ecco per insidie in senato fu ucciso da Decio Bruto et Cassio et da altri congiurati” (I quote from Paris, Bibliothèque nationale de France, ms. it. 2017, f. 48v). The translation is mine.

65 See Ferraù 1975 (as in n. 44), 369, n. 34.

66 "Alchuni passionata mente voleno dire che l'imperio non sia iusto, quali sono quelli che in comunità tirannizano sotto falso nome de libertà" (I quote from Paris, Bibliothèque nationale de France, ms. it. 2017, f. 18v). The translation is mine. See Ferraù 1975 (as in n. 44), ibid. 
empire [= the Roman Empire] against those who have long sought with great effort to remove him from Italy, which is his bride. ${ }^{67}$

To better understand this point, it should be remembered that during the fourteenth century the Visconti rulers claimed descent from the Counts of Angera and therefore from Anglus, who according to legend was the nephew of Aeneas. In 1397, Duke Gian Galeazzo Visconti obtained official recognition of this mythical genealogy from the Holy Roman Emperor Wenceslaus, as well as the title of Count of Angera and a legal claim to the city of Angera, near Varese, and its surrounding area, which over the centuries had been detached from ecclesiastical control by the Visconti rulers. As a result, Gian Galeazzo gave his second son, the future Duke Filippo Maria, the name of Anglo. ${ }^{68}$ Gian Galeazzo and Filippo Maria Visconti's mythical descent from Aeneas was solemnly proclaimed by Pietro da Castelletto in his eulogy on the death of Gian Galeazzo Visconti on 20 October 1402 and, albeit in a more nuanced way, by Pier Candido Decembrio's life of Filippo Maria Visconti, while Francesco Filelfo's De laudibus Philippi Mariae Angli (In Praise of Filippo Maria Anglo) insisted on Visconti's Italian and Lombard descent. ${ }^{69}$

This passage of Barzizza's commentary represents the fulfillment of Visconti's Caesarism: the duke of Milan, as heir of Caesar and Aeneas,

67 "Pensando esso Dio per sua presciencia l'alto effetto, el qual deveva uscir da lui Enea, che cioè il qual Enea fu nel ciel empireo eletto per padre de l'alma Roma et cetera. Ad nui nel tempo presente anchora per altra cagione non dé parer indegno si ad Enea fu cortese Dio, pensando questo alto effetto che da lui deveva uscire, cioè la illustre et excelsa casa de Visconti, la quale dapoi molti illustrissimi principi et altri magnanimi baroni ha produto al mondo, lo serenissimo duca nostro de Milano Philippo Maria non solamente per gubernacolo de l'imperio di sopra ditto, contra quelli che da Italia sua sposa con longo studio et gran per sforço lo cerchano di excludere" (I quote from Paris, Bibliothèque nationale de France, ms. it. 2017, ibid.). The translation is mine.

68 On the legend of the Counts of Angera and the imperial recognition of Visconti's title, see L. Simeoni, "Visconti”, in Enciclopedia italiana, vol. 35 (Roma, 1937), 440-442.

69 In his eulogy, Pietro da Castelletto lists 43 generations from Anglus to Galvano, Count of Angera, who defended Milan against Frederick Barbarossa in 1151, see G.A. Sassi, Appendix ad dissertationem apologeticam pro vindicanda Mediolano sanctorum corporum Gervasi, et Protasii antiquissima possessione (Mediolani, 1719), 14. Decembrio writes: "Vicecomitum originem antiquam sane et praeclaram extitisse multi prodidere, nomen autem sumpsisse putatur ab Angleriae comitibus," see Ianziti, Zaggia 2019 (as in n. 1), 2. Filelfo avers: "Non vereor affirmare Philippum Mariam Anglum non esse Phryga sed Italum, non Troianum, sed Insubrem, ex hac Gallia cisalpina, quam Italiae lumen ausim appellare; nec item Illiensem aut Dardanum, sed Mediolanensem omnino," see G. Benadduci (ed.), Francesco Filelfo, Orazione in lode di Filippo Maria Visconti duca di Milano. Edita per la prima volta secondo il Codice Riccardiano 779 (Tolentino, 1898), 3. 
has the divine right to rule Italy, which is his bride, and to fight those who persist in failing to surrender to his will - another not exactly peaceful allusion to Florence, but also to the Italian cities that were still at war with Milan, Venice first among them. ${ }^{70}$ This shows once again that the vernacular literature promoted by Filippo Maria Visconti should not be regarded as a mere courtly product, but rather as a formidable propaganda tool, which the duke of Milan used in a much more subtle and refined way than his father Gian Galeazzo, to the point that one could say that Filippo Maria was more conscious than the humanists in his service of the disruptive political power of the written page, and, in a certain sense, very ahead of his time in his awareness of the power of a media war. ${ }^{71}$

Filippo Maria Visconti's real ambition was not only to politically unify Italy under his own rule, but at the same time to linguistically unify the different literary traditions of the Italian cities under the aegis of a new Milanese-based vernacular literature. This ambitious cultural project suffered a sharp setback with the battle of Anghiari in 1440: after that, the Visconti court continued to play an important cultural role, with a new protagonist, Francesco Filelfo, who became the most prominent figure at the court of Francesco Sforza, but the downsizing of Milan's political ambitions against Florence resulted in a more marginal role for vernacular literature in Milan, to the advantage of an official literature more in line with humanistic canons. ${ }^{72}$

70 On the political tensions in the late 1430s, see Cognasso 1955 (as in n. 7), 328-337. On this passage of Barzizza's commentary, see Zaggia 1993 (as in n. 3), 347, n. 245; Id. 1998 (as in n. 44), 137-138.

71 Pier Candido Decembrio's Life of Filippo Maria Visconti illustrates the duke's efficient espionage system, see Ianziti, Zaggia 2019 (as in n. 1), 40-41; Hankins 2019 (as in n. 5), 144. This system, which was also applied to personal correspondence, can be considered as a form of media control per se.

72 As late as 1463 Pier Candido Decembrio sought (in vain) the favor of Francesco Sforza, dedicating to him a vernacular translation of Tito Livio Frulovisi's Vita Henrici V, preceded by a dedicatory letter in which Decembrio echoes the dedicatory letters of his earlier vernacular translations, see P. Ponzù Donato, "Pier Candido Decembrio tra biografia e filosofia della storia", Archivum Mentis 7 (2018), 59-76, at 73. On Francesco Filelfo's contribution to Milanese humanism, see D. Robin (ed.), Filelfo in Milan. Writings 14511477 (Princeton, NJ, 1991); Zaggia 1993 (as in n. 3), 356-367; J. De Keyser (ed.), Francesco Filelfo and Francesco Sforza. Critical Edition of Filelfo's Sphortias, De Genuensium deditione, Oratio parentalis, and his Polemical Exchange with Galeotto Marzio (Hildesheim - Zürich - New York, NY, 2018). 
By the early 1440s, Filippo Maria Visconti's dreams of the military but also literary - conquest of Florence and Italy were gone forever.

Università degli Studi di Firenze paolo.ponzudonato87@gmail.com 